\title{
PRINCIPALS' PERCEPTION OF GUIDANCE AND COUNSELLING SERVICES IN KWARA STATE SECONDARY SCHOOLS, NIGERIA: IMPLICATION FOR STAKEHOLDERS
}

\author{
Yusuf Suleiman ${ }^{1}$, Famolu Florence Bosede ${ }^{2}$, Adekola Kamil Lasisi ${ }^{3}$, \\ Mustapha Adam Ishola ${ }^{4}$
}

Final Received: $21^{\text {st }}$ April 2020

Final Proof Received: $29^{\text {th }}$ March 2021

\begin{abstract}
Students are often faced with numerous challenges, which can bring on stress, anxiety, depression or relationship problems with those around them. Because of the foregoing, this study examined the principals' perception of guidance and counselling in secondary schools. The study population consist of all principals in secondary schools in Kwara State, Nigeria. Non-probability sampling techniques (stratified, purposive and convenience) were employed to select 20 principals to participate in the study. An instrument titled "Interview Guide on Guidance and Counselling Services (IGGCS)" was used to collect relevant data from the principals while secondary data were obtained from the counselling department of the schools. Nvivo software (version 10) was used to analyse the data collected. The findings of the study revealed that principals believe the provision of counselling services had a significant impact on student's academic achievement, even though most of the secondary schools do not have a good counselling unit, qualified counsellors, and counselling facilities. This study recommends that a well-equipped counselling unit should be available in schools. Only certified counsellors should be deployed to offer counselling services to students. Lastly, students should be sensitized and encouraged by the school on the need for them to go for counselling to solve their numerous challenges.
\end{abstract}

Keywords: guidance and counselling services, school principals, kwara state

JOMSIGN: Journal of Multicultural Studies in Guidance and Counseling Website: http://ejournal.upi.edu/index.php/JOMSIGN

Permalink: https://ejournal.upi.edu/index.php/JOMSIGN/article/view/24159

How to cite (APA): Suleiman, Y., Bosede, F. F., Lasisi, A. K., Ishola, M. A. (2021). Principals' Perception of Guidance and Counselling Services in Kwara State Secondary Schools, Nigeria: Implication for Stakeholders. JOMSIGN: Journal of Multicultural Studies in Guidance and Counseling, 5(1), 58-83

This is an open-access article distributed under the terms of the Creative Commons Attribution 4.0 International License, which permits unrestricted use, distribution, and reproduction in any medium, provided the original work is properly cited.

\footnotetext{
${ }^{1}$ Department of Educational Management and Counselling, Faculty of Education, Al-Hikmah University, Nigeria; e-mail: yusufsuleiman@alhikmah.edu.ng

${ }^{2}$ Department of Guidance and Counselling, Faculty of Education, Osun State University, Osun State, Nigeria; e-mail: florencefamolu@yahoo.co.uk

${ }^{3}$ Department of Educational Management and Counselling, Faculty of Education, Al-Hikmah University, Nigeria; e-mail: draklasisi@gmail.com

${ }^{4}$ Department of Educational Management, Faculty of Education, University of Ilorin, Nigeria; e-mail: adamibnmustapha80@gmail.com
} 


\section{INTRODUCTION}

The establishment of a guidance and counselling unit in school is essential because the technological advancement in the world today poses vocational, educational and personal-social challenges which put the child in a state of anxiety, fear and stress of how to cope and adjust to the challenging situations. To reduce fear among pupils, guidance and counselling services are required in schools to assist them. These services enable students to function effectively within the school system in particular and the community at large thus making the child well-fulfilled (Andriušaitiene, 2020; Braddock, 2001; Egbochukwu, 2008; the Federal Republic of Nigeria, 2013; Fox \& Butler 2009; Yunusa, 2020). In Africa, according to the study conducted by Alemu (2013), it is reported that most secondary schools in the region had poor awareness about the presence of counselling services. Similarly, Wambui (2015) found that few students sought counselling services in secondary schools in Kiambu County of Kenya.

In the Nigerian context, because of the complexity of its political and socio-economic settings, many challenges are associated with students' negative behaviour in secondary school. The challenges include drug abuse, sexual exploitation, kidnapping, unstable homes, stealing, cultism, truancy (Ibrahim, Aloka, Wambiya \& Raburu, 2014; Universal Basic Education Commission, 2010). Mogbo, Obumneke-Okeke and Anyachebelu (2011) opined that recent trends in the education system in Nigeria, such as population explosion, examination malpractice, bullying, poor academic performance, quarrelling and other forms of maladaptive behaviours necessitated the need for effective provision of guidance and counselling services in schools. Also, Aluede (2000) and Anagbogu, Nwokolo, Anyamene, Anyachebelu and Umezulike, (2013) reported that several factors are militating against the effective provision of counselling services in secondary schools in Nigeria which include lack of trained counsellors, inadequate funding and lack of counselling equipment.

Furthermore, studies suggest that the provision of guidance and counselling services are needed for the success of students because it provides reflective thinking which assists in the coping ability of students in their academic endeavours (Bedi, Thomas, Sandhu \& Jain, 2020; Brown \& Trusty, 2005; Hossain \& Faisal, 2013; Nyamwange, Nyakan \& Ondima, 2012; Parsad, Alexander, Farris, Hudson \& Greene, 2003; Sink \& Stroh, 2003; Turnball, 
2006). It is against this background that the current study seeks to investigate the principals' perception of guidance and counselling services in secondary schools in Kwara State, Nigeria via a qualitative approach.

\section{LITERATURE REVIEW}

Several empirical studies have been conducted on the relationship between guidance and counselling services and academic achievement in school. Firstly, Modo, Sanni, Uwah and Mogbo (2013) conducted a study on guidance and counselling services as the coping measures for the academic achievement of students in secondary schools in Nigeria. The purpose of the research was to determine the influence of counselling services on students' academic achievement. The researchers adopted the ex-post facto design of the study. The target population was 2,250 senior secondary schools. Stratified random sampling was used to select the actual population, with 252 forming the respondents. The outcome of the study found a significant relationship between guidance and counselling services and academic performance in Nigerian secondary schools. Likewise, Chi (2006) investigated the effect of guidance services on student attitudes, study habits and academic performance in secondary schools. The researcher found that the presence of guidance services in secondary schools has a positive correlation with study habits, attitudes and academic achievement. The study observed that the scope of future studies should be widened.

Moreso, research carried out on the nexus between counselling services and students' behaviour in school by Tobia and Myrick (1999) and found that there was a positive relationship between counselling services and students' behaviour in terms of academic achievement. The researcher posited that better school counselling influenced the grades of the students in the sampled schools. The findings showed a significant relationship between counselling and academic achievement and more empirical studies were recommended. In the same vein, Sink, Akos, Turnbull and Mvududu (2008) investigated the comprehensive guidance programs and academic achievement in Washington state secondary schools. The findings of the study revealed a positive correlation between guidance and counselling programs and students' outcome. The researchers opined that guidance programs such as information, evaluation, placement, vocational and orientation services had a great influence on students' academic performance. Similarly, Lapan, Gysbers and 
Petroski (2001) carried out a survey study to determine the relationship between the availability of counselling services in school and the learning outcome of the students in Missouri schools. The findings revealed a positive relationship between the independent and dependent variables (counselling programs and academic performance) in the school.

Webb, Brigman and Campbell (2005) investigated the relationship between school counsellors and academic achievement in schools. The outcome of the findings was similar to other findings mentioned above. White and Edmondson (1998) studied the relationship between tutor counselling programs and student learning outcomes. Their findings found a positive relationship between school counsellors and academic achievement. It was concluded that the importance of counsellors in the school system cannot be compromised. The researchers recommend that there should be more studies on counselling services. Equally important, the study conducted by Turball (2006) also revealed a positive relationship between counselling services and students' learning outcome in school. The foregoing finding is similar to the one investigated by Dwyer and McNaughton (2004) who concurred that counselling services should be dispensed to students from time to time. The need for more studies was suggested by the researchers. Sink and Stroh (2003) conducted a study on raising the academic achievement of students through the implementation of guidance programs in schools. The findings revealed a positive significant relationship between guidance programs and students' academic performance. They submitted that academic performance relates to the proper implementation of school guidance programs. They expressed further that these programs align with the academic policies and programs.

Rupani, Haughey and Cooper (2012) investigated the impact of counselling services and students' learning capacity in schools. The outcome of the findings corroborates with other findings discussed above with a positive significant relationship between school counselling services and academic achievement. Also, Chireshe (2012), Dwyer and McNaughton (2004), Hossain and Faisal (2013), Ibrahim, Aloka, Wambiya and Raburu (2014), Lee, Olson, Locke, Michelson and Odes (2009) and McKenzie, Murray, Prior and Stark (2011) investigated the link between guidance and counselling services and students' achievement in secondary schools. Each study found a positive relationship between the impact of counselling services on students' academic achievement. They recommended that counselling 
services are one of the services that must be available from time to time in the school.

However, there are few studies conducted that are contrary to the aforementioned positive findings on the relationship between guidance and counselling services and academic achievement. For instance, Anagbogu et al. (2013) studied the challenges hampering the implementation of guidance services in secondary schools and student learning outcomes. The researchers employed a descriptive survey design for the study; the random sampling technique was used to select the population for the study. Specifically, counsellors formed the respondents of the study. A research instrument was designed to collect data from the respondents. The outcome of their findings showed a negative relationship between guidance programs and learning outcomes. The authors admitted that the findings were a result of poor facilities and equipment used for the study. Therefore, it was recommended that more studies should be conducted to know whether or not similar findings would be found or not. Troop and Tyson (2008) investigated the relationship between guidance programs and student learning outcomes. Their study adopted a survey to elicit data from the respondents. The outcome of their findings found a negative relationship between guidance programs and learning outcomes. They are of the view that the lack of counsellors in schools might be the reason for the findings. They suggested that future studies need to be carried out to empirically approve or disapprove their findings.

Buttressing the above findings, Aluede (2000) studied the influence of guidance and counselling services on academic achievement. The researcher adopted a survey method for the study. The outcome of the findings showed a negative relationship between guidance and counselling services and students' academic performance. He pointed out that the lackadaisical attitude of the government at all levels of education (primary, secondary and tertiary) is responsible for the lack of counselling services in the school system. He concluded that secondary schools in Nigeria with well-established guidance and counselling units are minimal and those that have a unit often underutilize the unit. He further observed that counselling services have not been rooted in the Nigerian educational system. Guidance service units in schools must be given the utmost attention to serving the purpose of assisting the students to adjust to the environment they find themselves in. Currently, counselling services in secondary schools in Nigeria are deficient. Dabone, Graham and Fabea (2015) conducted a study on the impact of counselling services on 
students' academic achievement in secondary schools in Cape Coast, Ghana. The study adopted an experimental approach. The outcome of the study revealed that there was no significant change in pre-test scores of the experimental and control groups. However, a significant change was found between the control group and post-test scores. Almon, Elias, Seotlwe and Mercy (2011) investigated the perceived challenges of counselling services in Botswana secondary schools via a mixed-methods approach (quantitative and qualitative). Interviews and questionnaires were used to collect relevant data for the study. Schools' principals were interviewed while questionnaires were administered to students. They found that teachers were not adequately prepared to teach guidance and that school heads did not supervise guidance because they lacked knowledge and skills in the subject. They also found that teachers experienced problems in the implementation of guidance because of the lack of support materials that could assist them in teaching guidance. In the same vein, a qualitative study conducted by Alemu (2013) focused on the perceived provision of guidance and counselling services in Ethiopian secondary schools using principals and counsellors as participants for the study. He found that most of the schools lacked counselling facilities.

Carl Rogers, one of the contributors of the humanistic approach, views people as having capacity and capability, and autonomy. They can recognise their potentials and positively change their lives. Guidance and counselling address humanistic aspects of learning, it is a school of thought that believes in the potential of people to develop from learning. Humanism thus gives preference to the study of human interests and needs. The main assumption of the theory is that human being exhibits behaviour out of values and intentionality (Brigman \& Campbell, 2003; Corey, 1990; Dunn, 2000; Gatrell, 2003; Huitt, 2001; Maree, 2020; Thiede, 2005; Owino, 2013; Waggoner, 2001; Venda \& Martinson, 2003). Seligman (2006) opined that the humanistic theory allows for the growth of a greater understanding of the environment which may ultimately assist individuals to resolve their challenges without the direct involvement of another party. Guidance and counselling services thus expose students to many experiences and provide them with decision-making skills, the ability to succeed in life and become self-actualised.

Ajowi and Simatwa (2010), Ludeman (2002), Mutie and Ndambuki (2003), Oye, Obi, Mohd and Bernice (2012) and Oyieyo (2012) asserted that the function of guidance and counselling personnel in secondary schools are enormous. They liaise with the school principal on the best way to provide 
counselling services for students; coordinate the counselling activities in school; provide information to students on career choice; Keep vital records of students in school; assist the students on how to relate with their peers and others outside the school premises; relate with the parents of the students on how to solve the problems facing the students; serving as a role model to students, and provide adequate data for student placement. Atulu and Etiobhio (2006) admitted that most of the school counsellors in Nigerian secondary schools had deviated from their functions/roles in the school system and some of the counsellors in the school system have been converted to teachers, which forced them not to face the core business of counselling in schools. Combining teaching and counselling for school counsellors is the order of the day in Nigerian secondary schools, and this had contributed to the below-par performance of counsellors in helping the students with their counselling needs. Furthermore, Aluede (2000), Chireshe (2008), Chireshe (2009) and Chireshe (2012) opined that multi-facet challenges are facing the operation of guidance and counselling services in the school system, the challenges are lack of counselling equipment, recruitment of unqualified counsellors, unavailability of students' information, parental factor, financial constraint, unfavourable school policy, etc. These challenges are well known at all levels of education (primary, secondary and tertiary) in Nigeria. Proffering solutions to the challenges facing guidance and counselling services in the school system would stem from the dilapidated state of the services in the school. The solutions to the challenges, not far-fetched, counselling, equipment, recruiting competent and qualified counsellors, and constant access to student' information as well as a good counselling policy is needed to make the services effective in the school system.

Taken the above studies together, it can be said that studies on the relationship between guidance and counselling services mostly carried out via a quantitative approach, given less attention to the qualitative approach. Thus, the focus of the current study is to know the perceptions of principals on guidance and counselling services in secondary schools in Kwara State, Nigeria using a qualitative approach. Given the reviewed literature, the following research questions were formulated to guide the study:

\section{Research Questions}

1. What are the contemporary issues on guidance and counselling services in secondary schools? 
2. What are the factors affecting guidance and counselling services in secondary schools?

3. What are the measures that can be used to ensure effective guidance and counselling services in secondary schools?

\section{Research Objectives}

1. To understand the contemporary issues on guidance and counselling services in secondary schools.

2. To identify factors affecting guidance and counselling services in secondary schools

3. To know measures that can be used to ensure effective guidance and counselling services in schools.

\section{METHOD}

\section{Participants}

The research design adopted for this study is the qualitative method. We used the method intending to capture the richness of the context and personal views of the subject. Also, the purpose of the qualitative method is to discover the variety because sample size and sampling strategy play no substantial in the selection of a sample ( Creswell, 2009). The population of the study consists of principals of secondary schools in Kwara State, Nigeria. Principals are considered for the study because they are responsible for the day to day running of their schools and they have comprehensive knowledge of happenings in their schools concerning the issue of school services, including guidance and counselling services. To select the participants, we used three techniques, which included stratified, purposive and convenience techniques to select them. Firstly, we used a stratified technique to classify all the secondary schools in Kwara State into three districts (south, central and north). Secondly, a purposive technique was used to select schools based on district while convenience technique was employed to select 20 principals. The use of convenience technique made it easy to select principals from the schools (Creswell, 2009; Gay \& Aisaran, 2000).

\section{Instrumentation}

An interview guide titled "Interview Guide on Guidance and Counselling Services (IGGCS)" was developed to elicit data from the participants. Questions in the interview were adapted from previous studies (Nyamwange et 
al., 2012; Parsad et al., 2003) conducted on guidance and counselling services in secondary schools. According to Burns (1997), an interview guide entails some questions to be asked based on research questions highlighted in the study. It is a document that covers vital information in which the interviewer will follow elicit information from the interviewee. The interview was considered appropriate because it helps the researcher to obtain suitable data, as it probes and explores participants' answers to collect in-depth views about their feelings and experiences. To ensure the trustworthiness of data, the interview guide was given to experts in the field of the study to check the quality of the questions and their relevance. The experts' corrections and observations were affected in the interview guide. Furthermore, a pilot study was conducted in one of the secondary schools outside the selected schools used for the main study to ensure that the interview guide is reliable and can be used for the main study.

\section{Ethical Consideration/Data Collection}

Before the commencement of the interview, we explained the purpose of the study to the participants. Also, the issue of confidentiality was explained to the participants. After permission to conduct the interview was granted by the schools' principals, the interview was conducted in all the selected secondary schools. Items used to conduct the interview are a digital audio tape recorder, laptop, iPad phone, biro, pencil, eraser and jotter. Besides, two research assistants were employed to assist in data collection.

\section{Data Analysis}

In line with the research questions and objectives of the study, data collected were analysed using Nvivo software. Specifically, Nvivo software was used to create nodes and generate models using a thematic approach as suggested by Creswell (2009).

\section{ANALYSIS}

\section{Data Transcription/Use of Nvivo Software}

After the interviews, we transcribed the data with the use of an audiotape, laptop, biro, pencil and jotter. Transcription of participants' views lasted between 20 (minimum) to 30 (maximum) minutes. The transcription was printed and coded to identify the main and sub-themes. The coding of the data was carried out based on the research questions of the study. After the manual coding of the data, we imported the softcopy of the data into Nvivo software 
to create nodes and models. The reason we used Nvivo is that it provides thorough coding and interpretation. It also helps in data management and makes research seamless (Buchannan \& Jones, 2010). According to Blismas and Dainty (2003), the use of Nvivo software helps to allow hyperlinking of the data and other external documents as well as the creation of conceptual nodes and models, which can be used to conclude the research. The table 1 below depicts the thematic analysis of the data collected.

\section{Table 1. Thematic analysis of the data collected}

Theme One: Issues on guidance and counselling services

Sub-themes:

1. Meaning of guidance and counselling services

2. Nature of guidance and counselling services

3. Provision of guidance and counselling services in school

4. Importance of guidance and counselling services on students' academic achievement

Theme Two: Factors affecting the provision of guidance and counselling services

\section{Sub-themes:}

1. Lack of trained counselling personnel

2. Inadequate counselling equipment

3. Poor funding

Theme Three: Measures on how to ensure effective guidance and counselling services school

Sub-themes:

1. Availability of qualified counsellors

2. Functional and conductive counselling unit

3. Proper funding of counselling unit 


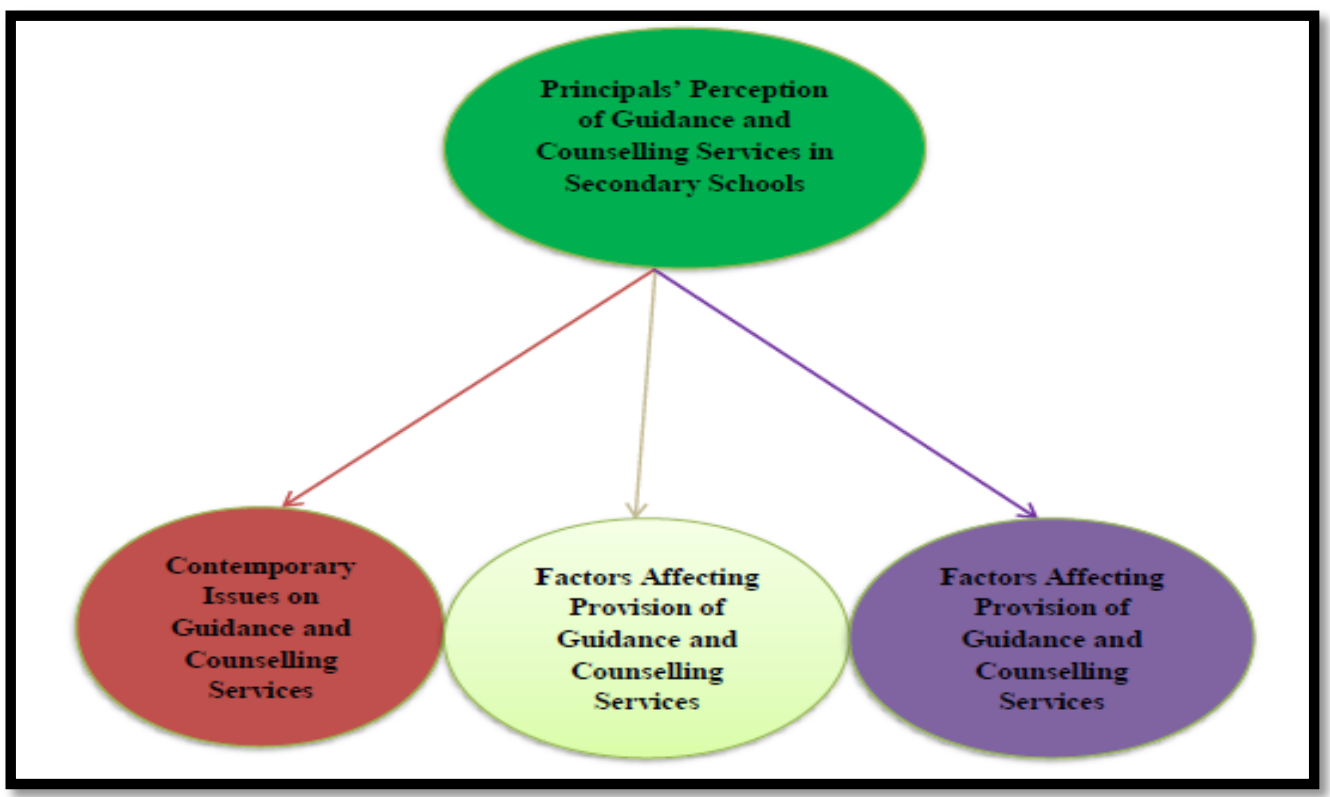

Figure 1 General Model on Principals' Perception of Guidance and Counselling Services in Secondary Schools

\section{Research Question One: What are the contemporary issues on guidance and counselling services in secondary schools?}

Reports of the interviews conducted shows that virtually all the informants subscribe to the role of guidance and counselling services in the development of students. The informants were probed with four salient questions on guidance and counselling services (i.e., meaning, nature, provision and importance of guidance and counselling services. The four questions constitute the sub-sub themes. Nvivo output shows the contemporary issues on guidance and counselling services school in the schools.

Informants 11, 15 and 13 described guidance and counselling services as:

"Services that are designed to guide students in need regarding personal, private and public needs with the hope of giving them assistance which requires the help of the school counsellor. Guidance and counselling services are very vital in the school system. Guidance and Counselling services are meant to assist students to adjust to the school environment for them to achieve their academic goals. It is a service that proffers solutions to the barrage of challenges or problems have in school. Guidance and counselling services are meant to restructure the life of the students in school." 


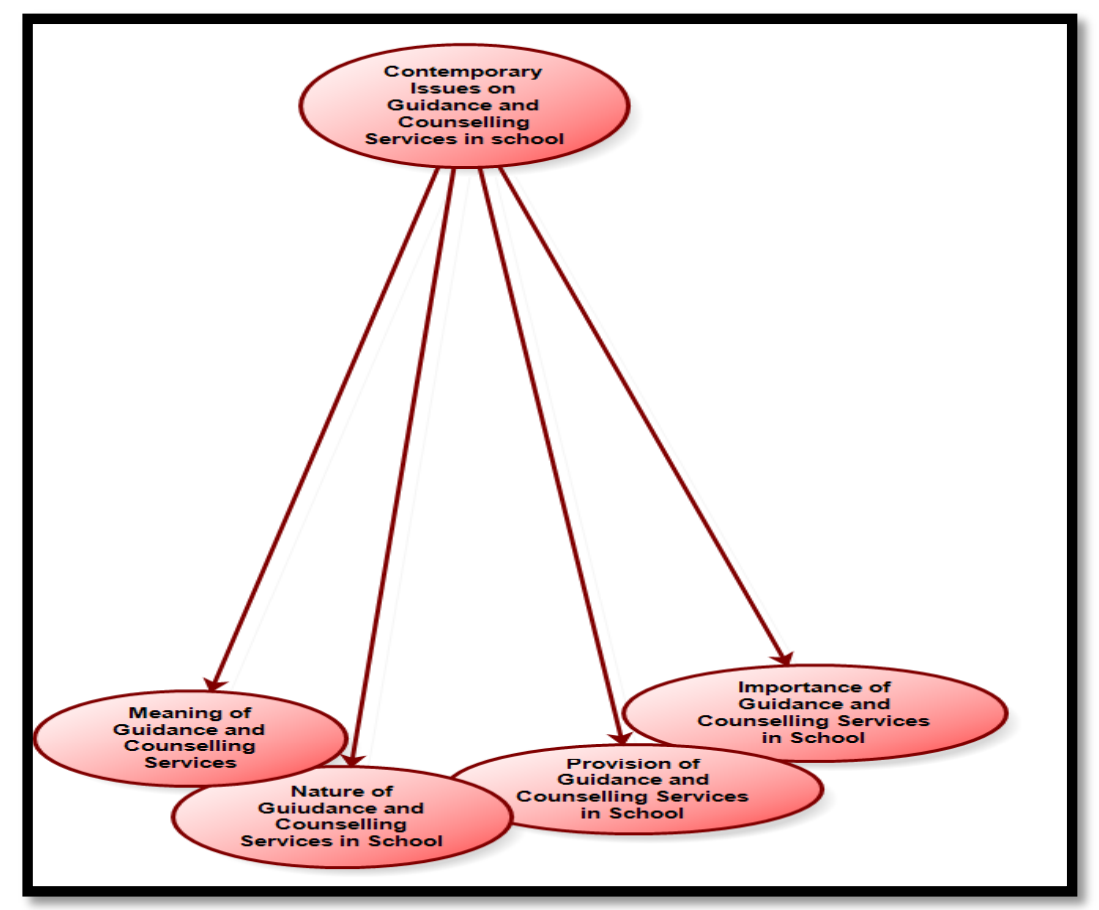

Figure 2 Contemporary Issues on Guidance and Counselling Services in School Meaning of Guidance and Counselling Services

Similarly, Informants $16,7,8,9$ and 14 subscribe to giving comprehensive meaning to what guidance and counselling services mean, they explained:

"Services meant to assist students to have a choice of their career. Guidance and counselling services are all about students' needs. It is supposed to take proper care of them when it is needed. Guidance and counselling service deal with moral behaviour and other vices of students in school. These services help to reshape the character of students. Guidance counselling services are designed to guide the students concerning their challenges in school. Guidance and counselling are a unit where the authority performs some duties with the students. Duties are in many ways; it encompasses academic, moral and others."

\section{Nature of Guidance and Counselling Services}

According to Informant 18, "our school has a functional counselling unit with a qualified counsellor, which is supported by teachers in providing counselling 
services for the students... The types of counselling services offer include information, career, vocational and other services of counselling." Informant 11 , in support of other informants, said that "...We have functional guidance and counselling unit with qualified counsellors who are in charge of managing the unit for... The school offers information, career, vocational and other counselling services to the students to guide them to perform better in their academic endeavours. Informant 14 and 19 explained that:

"We have a counselling unit with a qualified counsellor in charge of the unit. Counsellors in the unit are managing the counselling unit in our school. The counselling unit offers a variety of counselling services to students, which includes vocational service, information service, career services, etc. These counselling services are constantly provided to solve the multi-challenges facing the students in our school. The counsellor has a significant role to play in ensuring that students' problems are tackled."

\section{Provision of Guidance and Counselling Services in School}

Informants 14, 9, 13, 8 and 19 said, "counselling services are well provided in schools for the benefit of the students." Likewise, Informants 5, 20, 12 and 15 disclosed, “... all forms of counselling services (e.g., career, information etc.) are well provided in their schools". Informants 3 stated that "I can say categorically that counselling services are well provided for students in this school... we've just referred some students to the counselling unit for counselling... had it been you were here earlier, you would have met those students in a counselling unit of our school. Informants 4, 7, 16, 10, 17 and 18 also confirmed, “... counselling services are well provided for students in our school because counselling remains an integral part of the school system. These services are provided for students in my school."

\section{Importance of Guidance and Counselling Services on Students'Academic Achievement}

Informants 18, 20 and 8 added that:

"A school cannot do without counselling unit because it helps to guide students in career path. It helps students to perform well in their academic endeavours. It promotes academic excellence. It helps to instil discipline in students. It helps to solve the multi challenges facing 
students in the school. It helps to mould the character of the students. It establishes a positive relationship between students' parents and school regarding sharing of information as well as helping to mould the character of the students. It establishes a positive relationship between students' parents and school regarding sharing of information. It helps students in making the right decision concerning their career or discipline."

Research Question 2: What are the factors affecting the provision of guidance and counselling services in school?

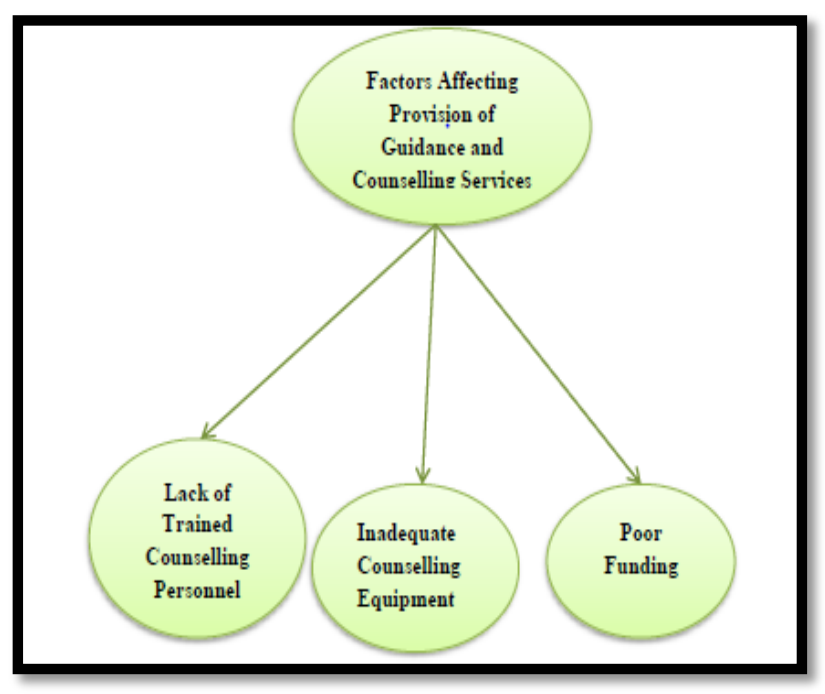

Figure 3 Factors Affecting Guidance and Counselling Services in Secondary Schools

\section{Lack of Trained Counselling Personnel}

The views of the informants (principals) in the selected secondary schools for the study attested to the foregoing disgusting trend. Informants 1, 2, 3, 6 and 4 explained thus:

"We have one (one in each school) trained counsellor in our school. But due to the large number of students that we have, we improvised by using our experienced teachers to assist the trained counsellor in providing adequate counselling services in school so that students problems can be attended to without wasting time. This improvised method has assisted us a lot in making sure that students get timely and adequate counselling services". 


\section{Inadequate Counselling Equipment}

Evidence from this study indicates that inadequate counselling equipment in school impedes the provision of adequate and quality counselling services, as submitted by most of the informants. Specifically, Informants 1, 2, 3, 6 and 4 are of the view that:

"To be candid, we do not have adequate counselling equipment in our school. Counselling equipment such as digital tape, recorder, computer discs, desk and laptops, printer, journals, magazines and newspapers, etc. The mentioned materials are missing in the majority of our schools."

The view of Informants 4, 7, 8, 5, 9, 10 and 11 is similar to the above view on inadequate counselling equipment in secondary schools. Below is the excerpt:

"Reality is that most secondary schools in this state do not have adequate counselling equipment like computer, printer, magazines and newspapers that are needed to provide counselling services for the students. This is affecting the growth of guidance and counselling services in the education sector."

\section{Poor funding}

According to the views of Informants 1, 2, 3, 6 and 4:

"Honestly, the guidance and counselling unit in our school is poorly funded. Provision is not made for the provision of counselling materials that may be needed by the counsellors to offer a wide range of services to their clients (students). Also, due to lack of fund, counselling personnel are restraint from carrying out their duties such as a visit to students' parents to discuss the challenges confronting their children. Besides, lack of fund does not allow counselling personnel to participate in workshops, seminars and conferences which are needed to increase their knowledge in counselling."

In the same vein, excerpts of informants on poor funding counselling unit in secondary schools are given below:

"Our counselling unit lack adequate funding, which hampers the provision of adequate and quality counselling services to students. You can see by yourself that in this counselling room, there are certain materials (e.g. counselling books) that are needed now to assist the 
counsellors which we are unable to provide due to financial constraint. There are other obligations that we need to perform but we could not do it due to unavailability of fund $(7,8,5,9,10 \& 11)$."

Research Question Three: What are the measures that can be used to ensure effective guidance and counselling services in secondary schools?

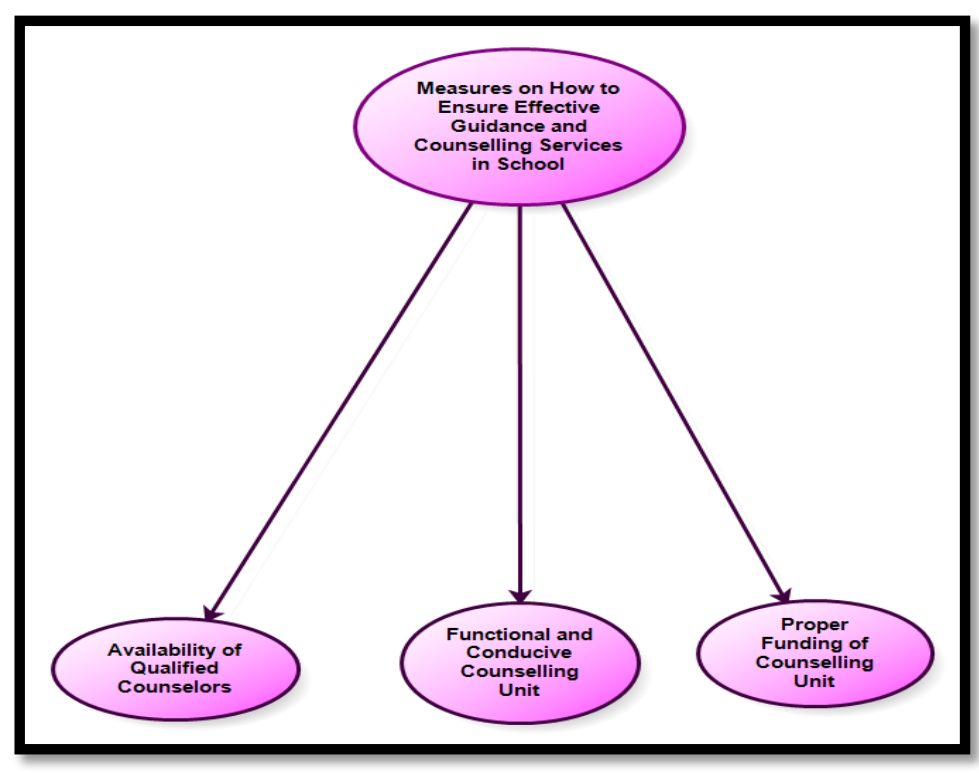

Figure 4 Measures on How to Ensure Guidance and Counselling Services in School

\section{Availability of Qualified Counselors}

According to Informants 1, 2 and 3:

"There is no doubt that if counsellors are in school, it will allow the school to solve the numerous challenges that students are facing. Thus, availability of qualified and competent counsellors in our schools is needed to improve counselling services."

"Due to population explosion as well as numerous challenges that students have in our secondary schools, trained counsellors should be recruited to offer comprehensive and quality counselling services to students. This will help to curb issues such as sexual harassment, drug abuse, cultism, etc. among students (6, 4, 8, 5, 9 \& 7)." 
Principals' Perception of Guidance and Counselling Services in Kwara State Secondary Schools, Nigeria: Implication for Stakeholders

\section{Functional and Conducive Counselling Unit}

Informants $1,2,3,7,4,8,5,9,10,11$ and 6 opined that:

"To revive guidance and counselling services in school, we need to have a functional clinic, which will be used to conduct counselling session. A good working environment is akin to the effective provision of all kinds of services that students need to correct their negative behaviours. If schools are provided with modern counselling room, as it is done in developed and developing countries, then the aim and objectives of counselling services will be achieved as contained in national policy on education."

\section{Sub-theme Three: Proper Funding of Counselling Unit}

The last measure suggested by the informants is the proper funding of the counselling unit. A summary of view on proper funding of counselling unit, according to Informants $12,1,9,10$ and 15 is indicated thus:

"Proper funding of counselling unit is sacrosanct. Therefore, efforts should be made by the government (local, state and federal) and other stakeholders in education (e.g. parents, Non-governmental organizations, philanthropists, etc) to ensure that the counselling unit is fully funded so that the unit can function effectively."

\section{DISCUSSIONS}

Through the findings, we were able to provide an answer to the research questions formulated for the study. The first research question asked about contemporary issues on guiding and counselling services in secondary schools. The first research objective was to understand the contemporary issues on guidance and counselling services in secondary schools. Firstly, on informants' views on the meaning of guidance and counselling services, the majority of the informants are aware of the meaning. They opined that guidance and counselling services are essential services that are meant to assist students to adjust to the school environment to achieve their academic goals. They are services that offer solutions to the barrage of problems that confront students in school. This finding is similar to several studies that have investigated the understanding of guidance and counselling services in school services. Chireshe (2012) and Modo et al. (2013) found that guidance and counselling connote the services that are designed to ameliorate the challenges 
facing the students in the school system. The study of Mutie and Ndambuki (2003) concurred that counselling in school is services that are sacrosanct in the school system. They are services needed to attend to the challenges of students so that students can be well guided. Secondly, the nature of counselling services given to the students in the school revealed that principals affirmed the majority of the schools offered counselling services such as career, vocational, career, information and other services that students need. This finding is congruent with the studies of Brown and Trusty (2005) and Hossain and Faisal (2013) who opined that counselling services such as information, career, placement, evaluation and referral services are needed to be offered to students in school. These types of services are holistic and help to correct students' bad behaviour. Thirdly, on whether counselling services are well provided for students in schools, our study found that counselling services are well provided for students who need it as confirmed by the schools as the majority of the informants are of the view that providing counselling services is a must. They opined that school that does not provide counselling services should not be called the school because the provision of counselling services is part of the curriculum content to be implemented so that the goals of secondary education can be achieved. The foregoing finding aligns with the study of Ludeman (2002) who concludes that the provision of guidance and counselling services in the school play a significant role in students' lives. Fourthly, on whether the provision of counselling services improve students' academic achievement in school. Our finding revealed that the provision of counselling services have a positive impact on student's academic achievement. Interestingly, informants submit that counselling services promote academic excellence in their schools. It also helps their students to be disciplined. The finding is similar to the studies conducted by Sink et al. (2008) and Tobia and Myrick (1999) who found that guidance and counselling services improved students' academic achievement. They opined that the availability of counselling services positively influenced the grades of students in schools. Lapan et al., (2001), Webb et al. (2005), White and Edmondson (1998) found that guidance and counselling services positively influenced students' academic achievement in secondary schools. Besides, the finding aligns with a humanistic theory that views people as having capacity, capability, autonomy, and that they can recognise their potentials and positively change their lives. Thus, guidance and counselling services expose 
students to many experiences and provide them with decision-making skills and the ability to succeed in school (Seligman, 2006).

The second research question asked on factors that affect the provision of guidance and counselling services in secondary schools? The second research objective was to identify factors that are affecting the provision of guidance and counselling services in secondary schools. Informants agreed that three factors affect the provision of guidance and counselling services in secondary schools. They include a lack of trained counsellors, inadequate counselling equipment and poor funding. Firstly, most of the secondary schools lack trained counsellors. Teachers were converted to counsellors and most of the converted teachers did not possess counselling certificate. Secondly, the majority of the schools do not have adequate counselling facilities/equipment such as a computer (desktop and laptop), printer, journals, newspapers, magazines, internet connection, basic furniture, notice board, suggestion box for students to slot in their thoughts and bookshelves. Thirdly, we found that funding is another factor affecting the provision of guidance and counselling services. Most of the schools do not have the financial wherewithal to procure guidance and counselling facilities. The foregoing finding is consistent with the study of Aluede (2000) and Wambui (2015) who found that factors affecting guidance and counselling services include poor funding, lack of counselling facilities and personnel. The finding is also congruent with the studies of Almon et al., (2011) and Anagbogu et al. (2013) who opined that the unavailability of guidance and counselling equipment hindered the effective provision of counselling services in secondary schools.

The third research question was on what are the measures that can be used to ensure effective guidance and counselling services in secondary schools? The third research objective was to know measures that can be used to ensure effective guidance and counselling services in schools. Interestingly, our finding revealed three measures that can be used to ensure effective counselling services in secondary schools. The measures are the availability of qualified counsellors, availability of functional and conducive counselling unit and proper funding of counselling unit. This finding is consistent with the study of Mogbo, Obumneke-Okeke and Anyachebelu (2011) who are of the view that the availability of counselling facilities will help to solve students' numerous challenges. They emphasized that adequate funding for the maintenance and sustainability of counselling services are essential in schools. Similarly, Dwyer and McNaughton (2004), McKenzie et al. (2011) and 
Rupani, Haughey and Cooper (2012) found that guidance and counselling facilities must be available to improve the academic standard of students.

Taken the above findings together, the present study has contributed to the body of knowledge in two ways. Firstly, the findings of the study will be useful to school principals, government and stakeholders in education on how to improve the provision of guidance and counselling in secondary schools in Kwara State, Nigeria. Methodologically, the literature review revealed that most of the studies on guidance and counselling services were conducted via a quantitative approach (Dwyer \& McNaughton, 2004; Lapan et al. 2001; Webb et al., 2005; White \& Edmondson, 1998), showing few studies on a qualitative approach. Thus, this study investigated perceptions of principals on guidance and counselling services via a qualitative approach. Secondly, the use of Nvivo software for the analysis in this study is another important methodological contribution because most of the past studies used manual analysis (e.g. Alemu, 2013; Almon et al., 2011) in their studies. Therefore, the use of Nvivo software provides more rigorous and thorough coding and interpretation of the data.

\section{Implications for Stakeholders}

1. The idea of teacher-counsellor should be reconsidered in secondary schools.

2. At least, two qualified and competent counsellors should be available in school.

3. Since the implementation of guidance and counselling programmes is needed to achieve the goals of secondary education, the government at all levels (Local, State and Federal) should provide guidance and counselling unit (clerical staff room and consulting room) in all public secondary schools and should mandate owners of private schools to do so.

4. Other stakeholders in education (such as Non-Governmental Organisations (NGOs), Philanthropists, Parent- Teachers' Association (PTA), Banks, etc) should assist in providing counselling equipment to secondary schools.

5. The counselling unit should be equipped with modern guidance and counselling facilities, which include television, radio, computer (desktop and laptop), cassette, CDs, printer, projector, journals, magazines, notice board, suggestion board, tables and chairs, shelving for keeping and retrieving of students' folders.

6. Counselling services such as referral, vocational, information, career and placement, and evaluation should be provided for students in schools. 
Principals' Perception of Guidance and Counselling Services in Kwara State Secondary Schools, Nigeria: Implication for Stakeholders

7. Students should be sensitized and encouraged by the school on the need for them to go for counselling to solve their numerous challenges.

\section{CONCLUSION AND RECOMMENDATION}

It is clear from the findings that the three objectives had been achieved. Even though guidance and counselling services were provided and have a positive impact on student's academic achievement in secondary schools, nevertheless, there are burning issues that need to be addressed to improve guidance and counselling services. The issues include lack of trained counsellors, inadequate counselling equipment and poor funding in the majority of the schools.

\section{REFERENCES}

Akunne, L. I., \& Nwadinobi, V. N. (2020). Administrators rating of school counsellor's competencies in information, counselling and follow-up service delivery. Advances in Research, 11-17.

Ajowi, J. O., \& Simatwa, E. M. (2010). The role of guidance and counseling in promoting student discipline in secondary schools in Kenya: A case study of Kisumu district. Educational Research and Reviews, 5(5), 263272.

Alemu, Y. (2013). Assessment of the Provisions of Guidance and Counseling Services in Secondary Schools of East Harerge Zone and Hareri Region, Ethiopia. Middle Eastern \& African Journal of Educational Research, 2, 28-37.

Almon, S, Elias, M, Seotlwe and Mercy, R. (2011). Perceived challenges of implementing the guidance subject in Botswana primary schools. Journal of Social Sciences, Vol. 28(1): 1-11.

Aluede, O. O. (2000). The realities of guidance and counseling in Nigeria secondary schools: Issues and benefits. Guidance and Counseling, 15(2), 22-26.

Andriušaitienè, D. (2020). Vocational guidance-GPS for management of human resource development: does it work in Lithuania. Business, Management and Education, 18(1), 56-72.

Anagbogu, M. A., Nwokolo, C. N., Anyamene, A. N., Anyachebelu, F. E., \& Umezulike, R. Q. (2013). Professional challenges to counselling practice in primary schools in Anambra State, Nigeria: The way forward. Int $J$ Psychol Couns, 5(5), 97-103. 
Ary D, Jacobs LC, Razavier A (1997). Introduction to Research in Education. 5th Edition. New York: Harcourt Brace College Publishers.

Atulu, W.L. \& Etiobhio, I. (2006). Counseling Program at Thika High School for the Blind, Kenya. Journal of the International Association of Special Education, 11(1).

Bedi, R. P., Thomas, P. A., Sandhu, D., \& Jain, S. (2020). Survey of counselling psychologists in India. Counselling Psychology Quarterly, 33(1), 100-120.

Blismas, N. G., \& Dainty, A. R. (2003). Computer-aided qualitative data analysis: panacea or paradox?. Building research \& information, 31(6), 455-463.

Braddock, B. (2001). Guidance and counseling services and Studentse school life. African Journal of Guidance and Counselling, 1(1), 007-015.

Brigman, G., \& Campbell, C. (2003). Helping students improve academic achievement and school success behavior. Professional School Counseling, 91-98.

Brown, D., \& Trusty, J. (2005). School counselors, comprehensive school counseling programs, and academic achievement: Are school counselors promising more than they can deliver?. Professional School Counseling, 9(1), 1-8.

Buchanan, J., \& Jones, M. L. (2010). The efficacy of utilizing Nvivo for interview data from the electronic gaming industry in two jurisdictions. Online Submision.

Chi, A. H. (2006). Effect of guidance services on study attitudes, study habits and academic achievement of secondary school students. Bulletin of Education \& Research, 28(1), 35-45.

Chireshe R, Chireshe E 2009. Sexual harassment of female students in three selected high schools in urban Masvingo, Zimbabwe. Agenda, 80: 8896.

Chireshe, R. (2008). The evaluation of school guidance and counselling services in Zimbabwe. The Nigerian Journal of Guidance and Counselling, 13(2), 54-68.

Chireshe, R. (2012). School guidance and counselling needs assessment in Zimbabwean secondary schools. Anthropologist, 14(1), 17-24.

Corey G 1990. Theory and Practice of Counselling and Psychotherapy. 4th Pacific Groove: Brooks/Cole Publishing Company. 
Creswell, J. (2009). Research design: Qualitative, quantitative, and mixed methods approaches. SAGE Publications, Incorporated.

Dabone, K. T., Graham, Y. A., \& Fabea, I. B. (2015). Impact of Guidance and Counseling on Academic Performance. Research on Humanities and Social Sciences, 5(8), 225-227.

Dunn,L.(2000).TheoriesofLearning.From $<$ http://www.brookes.u.k.services/oc sd2_learntch/theories.html..

Dwyer, S. C., \& McNaughton, K. (2004). Perceived needs of Educational Administrators for Student Services Offices in a Chinese Context School Counseling Programs Addressing the Needs of Children and Teachers. School Psychology International, 25(3), 373-382.

Egbochukwu, E.O.(2008). Guidance and Counselling: A Comprehensive Text. Benin, Uniben Press.

Federal Republic of Nigeria (FRN) (2013). National Policy on Education. Lagos, Nigeria: NERDC.

Gabriel, A. O. (2008). Multi Grade Teaching: Implications for the Universal Basic Education in Nigeria. Abuja: UBEC.

Gartrell PE 2003. The Power of Guidance: Teaching Socioemotional Childhood Classrooms. From<http:// www.academicsuperstone.com/markeldisp.html.

Hossain, S., \& Faisal, R. A. (2013). Guidance and Counseling Services in Schools of Bangladesh: An Exploratory Study. Online Submission.

Huitt, W (2001). Motivation to Learn: An Overview. http://chiron.valdosta.edu/whitt/co/motivation/motivate.html.

Ibrahim, F. R., Aloka, P. J., Wambiya, P., \& Raburu, P. (2014). Perceptions on the Role of Guidance and Counselling Programme on Kenyan Secondary School Students' Career Decision Making. Journal of Educational and Social Research, 4(6), 313.

Lapan, R. T., Gysbers, N. C., \& Petroski, G. F. (2001). Helping seventh graders be safe and successful: A state-wide study of the impact of comprehensive guidance and counseling programs. Journal of Counseling \& Development, 79(3), 320-330.

Lee, D., Olson, E. A., Locke, B., Michelson, S. T., \& Odes, E. (2009). The effects of college counseling services on academic performance and retention. Journal of College Student Development, 50(3), 305-319. 
Ludeman, R. B. (2002). The role of student affairs and services in Higher Education: A practical manual for developing, implementing, and assessing student affairs programs and services. Online Submission.

Maree, J. G. (2020). Innovative career construction counselling for a creative adolescent. British Journal of Guidance \& Counselling, 48(1), 98-113.

McKenzie, K., Murray, G. C., Prior, S., \& Stark, L. (2011). An evaluation of a school counselling service with direct links to Child and Adolescent Mental Health (CAMH) services. British Journal of Guidance \& Counselling, 39(1), 67-82.

Modo, F., Sanni, K., Uwah, C., \& Mogbo, I. (2013). Guidance and Counseling Services in Secondary School as Coping Strategy for Improved Academic Performance of Students in Akwa Ibom State, Nigeria. Research on Humanities and Social Sciences, 3(4), 43-47.

Mogbo I.N, Obumneke-Okeke I.M \& Anyachebelu, F.E (2011). Implementation of guidance and counseling services in Nigerian schools. Journal of Emerging Trends in Educational Research and Policy Studies (JETERAPS) 2 (5): 361-264.

Mutie, G., \& Ndambuki, J. (2003). Guidance and counselling services in public universities in Kenya. Journal of Emerging Trends in Educational Research and Policy Studies, 3(2), 151.

Nyamwange, C. B., Nyakan, P. O., \& Ondima, P. C. (2012). Assessment of Challenges facing Secondary School Guidance and Counselling Teachers in Nyamira District, Kenya. Journal of Education and Practice, 3(16), 41-47.

Okobiah, O. C. and Okorodudu, R. I. (2006). Concepts of guidance and counselling. In O. C. Okobiah and R. I. Okorodudu (editors) Issues concepts, theories and techniques of guidance and counselling BeninCity: Ethiope Publishers.

Ololube, N. P., Onyekwere, L. A., \& Agbor, C. N. (2016b). Effectively managing inclusive and equitable quality education to promote lifelong learning opportunities (LLO) for all. Journal of Global Research in Education and Social science, 8(4), 179-195.

Owino, E. A. (2013). An exploration of nature of guidance and counseling services in selected secondary schools in Eldoret Municipality, Kenya. Journal of Emerging Trends in Educational Research and Policy Studies, 5(1), 65-72. 
Oye, N. D., Obi, M. C., Mohd, T. N., \& Amos, B. (2012). Guidance and counseling in Nigerian secondary schools: the role of ICT. International Journal of Modern Education and Computer Science, 4(8), 26.

Oyieyo, D. M. (2012). Influence of guidance and counselling on students' discipline in public secondary schools in Kabondo division, Kenya (Doctoral dissertation, University of Nairobi, Kenya).

Parsad, B., Alexander, D., Farris, E., Hudson, L., \& Greene, B. (2003). High School Guidance Counseling. ED Tabs.

Rupani, P., Haughey, N., \& Cooper, M. (2012). The impact of school-based counselling on young people's capacity to study and learn. British Journal of Guidance \& Counselling, 40(5), 499-514.

Seligman SG 2006. Constructivist Learning Theory. From<http://www.exploratorium.edu/IFI/resources/constructivistlearnin g.html.

Sink, C. A., \& Stroh, H. R. (2003). Raising achievement test scores of early elementary school students through comprehensive school counseling programs. Professional School Counseling, 6, 350-365.

Sink, C. A., Akos, P., Turnbull, R. J., \& Mvududu, N. (2008). An investigation of comprehensive school counseling programs and academic achievement in Washington State middle schools. Professional School Counseling, 12(1), 43-53.

Thiede, B., Höhenwarter, W., Krah, A., Mattow, J., Schmid, M., Schmidt, F., \& Jungblut, P. R. (2005). Peptide mass fingerprinting. Methods, 35(3), 237-247.

Tobias, A. K., \& Myrick, R. D. (1999). A peer facilitator-led intervention with middle school problem-behavior students. Professional School Counseling.

Troop, T., \& Tyson, C. P. (2008). School nurses, counselors, and child and family support teams. NC Med J, 69(6), 484-486.

Turnball, C.O. (2006). School counseling and student outcomes: Summary of six statewide studies. Professional School Counseling, 16(2), 146-153.

Universal Basic Education Commission (UBEC) (2010). Manual for the Retraining of Basic Education Teachers and Basic Education Managers: Continuous Assessment Guidance and Counseling. Http: www.ubeconline.com.

Venda H, Martinson L (2003). Role of the Teachers in Teaching Guidance Instruction. New York: Teachers'College Press. 
Waggoner R 2001. Role of Guidance Teacher. From<http:/ /www.Biblicatheism.con.

Wambui, A. (2015). Effectiveness of guidance and counselingservices in secondary schools in kenya: a case study of githunguri sub-county in kiambu county. American Journal of Educational Science, Vol. 1, No. 4, 2015, pp. 204-209.

Webb, L. D., Brigman, G. A., \& Campbell, C. (2005). Linking School Counselors and Student Success: A Replication of the Student Success Skills Approach Targeting the Academic and Social Competence of Students. Professional School Counseling.

Yunusa, S. (2020). Evaluating application of information and communication technology in patronizing guidance and counseling services among undergraduate Students in Selected North-Western Universities in Nigeria. In Sustainable Development and Social Responsibility-Volume 2 (pp. 65-71). Springer, Cham. 